\title{
COGNITIVE DISABILITY AESTHETICS
}

Visual Culture, Disability Representations, and the (In)Visibility of Cognitive Difference 
This page intentionally left blank 


\section{COGNITIVE DISABILITY AESTHETICS}

Visual Culture, Disability Representations, and the (In)Visibility of Cognitive Difference

BENJAMIN FRASER

UNIVERSITY OF TORONTO PRESS

Toronto Buffalo London 
(C) University of Toronto Press 2018

Toronto Buffalo London

utorontopress.com

Printed in the U.S.A.

ISBN 978-1-4875-0233-1

( Printed on acid-free, $100 \%$ post-consumer recycled paper with vegetable-based inks.

Toronto Iberic

\section{Library and Archives Canada Cataloguing in Publication}

Fraser, Benjamin, author

Cognitive disability aesthetics : visual culture, disability representations, and the (in)visibility of cognitive difference / Benjamin Fraser.

(Toronto Iberic ; 32)

Includes bibliographical references and index.

ISBN 978-1-4875-0233-1 (cloth)

1. Disability studies. 2. Aesthetics. 3. Cognition disorders - Social aspects Spain. 4. Popular culture - Spain. 5. Arts - Spain. I. Title. II. Series: Toronto Iberic ; 32

HV1568.2.F73 $2018 \quad$ 704.9'496168 C2017-906090-2

This book has been published with the assistance of the Thomas Harriot College of Arts and Sciences at East Carolina University.

University of Toronto Press acknowledges the financial assistance to its publishing program of the Canada Council for the Arts and the Ontario Arts Council, an agency of the Government of Ontario.

Canada Council for the Arts
Conseil des Arts du Canada 
For Ben, Abby, and Judd 
